\title{
First Records of the Southern Red-backed Vole, Myodes gapperi, in the Yukon
}

\author{
Thomas S. Jung ${ }^{1}$, Amy M. Runck ${ }^{2}$, David W. NAgOrSEN ${ }^{3}$, Brian G. Slough ${ }^{4}$, and Todd Powell 5,6 \\ ${ }^{1}$ Yukon Department of Environment, Fish and Wildlife Branch, P.O. Box 2703, Whitehorse, Yukon Y1A 2C6 Canada; \\ e-mail: thomas.jung@gov.yk.ca \\ ${ }^{2}$ Department of Biological Sciences, Idaho State University, 650 Memorial Drive, Pocatello, Idaho 83209-8007 USA \\ ${ }^{3}$ Mammalia Biological Consulting, 4268 Metchosin Road, Victoria, British Columbia V9C 3Z4 Canada \\ ${ }^{4} 35$ Cronkhite Road, Whitehorse, Yukon Y1A 5S9 Canada \\ ${ }^{5}$ Yukon Department of Environment, Fish and Wildlife Branch, P.O. Box 194, Watson Lake, Yukon Y0A 1C0 Canada \\ ${ }^{6}$ Current address: Alberta Department of Sustainable Resource Development, Fish and Wildlife Division, P.O. Box 9915, \\ Fort McMurray, Alberta T9H 2K4 Canada
}

Jung, Thomas S., Amy M. Runck, David W. Nagorsen, Brian G. Slough, and Todd Powell. 2006. First records of the Southern Red-backed Vole, Myodes gapperi, in the Yukon. Canadian Field-Naturalist 120(3): 331-334.

Twenty Southern Red-backed Voles, Myodes gapperi, were collected in July 2004 in the LaBiche River valley of southeastern Yukon. Specimens were identified using morphological characteristics and analysis of cytochrome $b$ gene sequences. These are the first records of this species in the Yukon. No Northern Red-backed Voles, M. rutilus, were collected and it is not known whether the two species are sympatric or parapatric in the Yukon. Further survey work is needed in southeastern Yukon to better delineate the extent of the northwestern range of this species and the extent, if any, of introgression with $M$. rutilus.

Key Words: Southern Red-backed Vole, Myodes gapperi, distribution, Yukon.

The Southern Red-backed Vole (Myodes [formerly Clethrionomys see Musser et al. 2005] gapperi) is broadly distributed across the boreal, montane, Pacific coastal, and other conifer-dominated forests of North America (Banfield 1974; Merritt 1981; Batzli 1999). Youngman (1975) did not report M. gapperi from the Yukon, in part, because he was of the opinion that $M$. gapperi and the Northern Red-backed Vole (M.rutilus) were conspecific. Cook et al. (2004), however, provided molecular data that reinforced the separate status of $M$. gapperi and $M$. rutilus. North American species of Myodes, including M. gapperi and M.rutilus, are cryptic and field identification is highly problematic where congeners come into contact (Merritt 1981; McPhee 1984; Runck 2001, Nagorsen 2002, 2005; Cook et al. 2004). Therefore, we considered that M.gapperi may have been overlooked in the Yukon due to the difficulty in distinguishing specimens from M. rutilus in the field, and a general paucity of mammalian diversity surveys in most of the Yukon. Based on the distribution of $M$. gapperi in adjacent northeastern British Columbia and southwestern Northwest Territories (Banfield 1974; Nagorsen 2005) we suspected the greatest likelihood of finding the species in the Yukon was in the Liard River Watershed. In summer 2004, we undertook a brief field survey of mammalian diversity in the boreal forest of southeastern Yukon, partially with an aim to procuring specimens of $M$. gapperi. Here, we provide the first records of the Southern Red-backed Vole in the Yukon.

\section{Methods}

On 28 July - 2 August 2004, we used pitfall and snap traps to collect shrews and rodents in the LaBiche River Valley $\left(60.126^{\circ} \mathrm{N}, 124.064^{\circ} \mathrm{W}\right)$ of southeastern Yukon. Seven habitats were sampled: wet meadows and shrub thickets adjacent to Beaver (Castor canadensis) ponds; xeric grassy meadows; riparian old-growth White Spruce (Picea glauca) forest; lowland Black Spruce (Picea mariana) forest; subalpine old-growth Spruce-fir (Abies lasiocarpa) forest; second-growth mixedwood forest; and regenerating clearcut forest. All habitats were sampled with snap traps. We established 14 variable length traplines (ca. $100 \mathrm{~m}-250 \mathrm{~m}$ ) in each of the seven habitat types. Trap stations were set $10 \mathrm{~m}$ apart on the traplines. One Museum Special snap trap and one Victor snap trap (Woodstream, Lititz, Pennsylvannia) were set at each trapping station. Traps were baited with oats and peanut butter, run for 2-3 days and checked each morning. In addition to the snap traps, we established three traplines of metal conical pitfall traps in the wet meadow habitats, primarly to capture soricids. Pitfall traps were $25 \mathrm{~cm}$ in height and $15 \mathrm{~cm}$ in diameter at the top. Pitfall traps were also arranged in traplines with one trapline in each of the wet meadows sampled. Traps were spaced about $10 \mathrm{~m}$ apart, with 15 or 20 traps per trapline, and installed flush with the ground surface. Pitfall traps were not baited and they were left open for 3-5 days. Each morning we checked the traps and processed the captures. 
Captures were tentatively identified to species, measured, aged, weighed, sexed, and examined for reproductive condition. Whole carcasses were frozen on site. Species were tentatively identified in the field using morphological, pelage, and dental characteristics, following Nagorsen (2002) and van Zyll de Jong (1983). Because of the difficulty in distinguishing $M$. rutilus from $M$. gapperi in the field, we undertook subsequent laboratory investigations at Idaho State University (Pocatello, Idaho) to confirm our field identifications. All skulls were examined for fusion of the post-palatal bridge (Merritt 1981; Nagorsen 2002) and the first 600 base pairs (bp) of mitochondrial cytochrome $b$ gene were examined to confirm species identification. Restriction enzyme screening and sequencing of cytochrome $b$ followed established protocols for Myodes (Runck and Cook 2005). All individuals underwent restriction enzyme digestion using the restriction enzyme ALU I to determine the presence of the restriction site AGCT which is found in the $600 \mathrm{bp}$ fragment of the cytochrome $b$ gene in $M$. rutilus but not M. gapperi (Runck 2001). Five random individuals were sequenced for the first $600 \mathrm{bp}$ of the cytochrome $b$ gene and were used in a phylogenetic reconstruction using published sequences of Myodes (Cook et al. 2004; Runck and Cook 2005), representing $M$. gapperi $(n=10), M$. rutilus $(n=2)$, M. californicus $(n=1), M$. glareolus $(n=1)$, and M. rufocanus $(n=1)$. Sequences for specimens not collected in LaBiche (Figure 1) were taken from GenBank. Phylogeographic reconstruction was conducted using neighbor-joining framework in PAUP b10 (Swofford 2002) using the Tamura and Nei (1993) model of sequence evolution as determined through Modeltest (Posada and Crandall 2000).

\section{Results and Discussion}

We captured 20 Myodes during sampling. Field identification, based on morphological (tail and pelage) characteristics, suggested that all captures were of $M$. gapperi. Further, 15 of the 20 specimens had complete post-palatal bridges, which is a primary diagnostic characteristic of M. gapperi (Merritt 1981; Nagorsen 2002). Two specimens had incomplete post-palatal bridges and the bridges of a further three were broken by the traps and not usable as a diagnostic character. Genetic analyses using restriction enzyme screening and sequencing of cytochrome $b$ gene confirmed that all 20 specimens of Myodes collected in the LaBiche River Valley were M. gapperi (Figure 1).

The Southern Red-backed Vole is now added to the list of mammals in the Yukon. This is the first additional rodent found in the Yukon since Youngman (1975). These 20 specimens were deposited at the Museum of Southwestern Biology at the University of New Mexico (Albuquerque, New Mexico).

Capture rates were 0.28 per 100 trap nights (TN) and 1.32 per $100 \mathrm{TN}$ in pitfall and snap traps, respec- tively. Captures of M. gapperi represented the range of sex and age classes ( 5 adult females, 7 adult males, 5 juvenile females, and 3 juvenile males), confirming that a breeding population was present. M. gapperi were taken in all of the habitats sampled. Species caught in association with M. gapperi in the LaBiche River Valley included: Meadow Voles (Microtus pennsylvanicus, $n=14$ ), Deer Mice (Peromyscus maniculatus, $n=13$ ), Meadow Jumping Mice (Zapus hudsonius, $n=10$ ), Eastern Heather Vole (Phenacomys ungava, $n=1$ ), Masked Shrew (Sorex cinereus, $n=1$ ), Pygmy Shrew (Sorex hoyi, $n=1$ ), and Dusky Shrews (Sorex monticolus, $n=2$ ).

We do not know the extent of the range of the Southern Red-backed Vole in the Yukon. They have been collected, however, near Fort Liard, Northwest Territories (S. Carrière, unpublished data; Runck and Cook 2005). Specimens from near Watson Lake, Yukon (ca. $270 \mathrm{~km} \mathrm{~W}$ of the present study; $n=43$ ), were also analyzed in the lab using skull and genetic characters and they were determined to be M.rutilus (T. S. Jung and A. M. Runck, unpublished data), suggesting that M. gapperi may not be widely distributed in southern Yukon. Perhaps $M$. gapperi is restricted in the Yukon to the extension of the Boreal Plain ecoregion in the extreme southeast. Further surveys from nearby river valleys, and subsequent DNA analysis, are needed to better document the ranges and contact zone of $M$. gapperi and M. rutilus in southeastern Yukon and adjacent British Columbia and Northwest Territories. Our discovery of M. gapperi in extreme southeastern Yukon, along with that of the Yukon's only records of Northern Long-eared Bats (Myotis septentrionalis; Jung et al. 2005) and other taxa (e.g., some species of neotropical migrant passerines: Eckert et al. 1997), suggests that this ecoregion may be a zoogeographically unique part of the Yukon.

\section{Acknowledgments}

The staff of Devon Canada Corporation's LaBiche River Gas Plant kindly went out of their way to accommodate us and provide logistical support. Funding was provided by the Yukon Department of Environment, NatureServe Yukon, and a Northern Research Endowment Grant from the Northern Research Institute, Yukon College, to B. Slough. Thoughtful comments from S. Cannings, and five anonymous reviewers improved the manuscript.

\section{Literature Cited}

Banfield, A. W. F. 1974. The mammals of Canada. University of Toronto Press, Toronto, Ontario. 438 pages.

Batzli, G. O. 1999. Northern red-backed vole, Clethrionomys rutilus. Pages 616-617 in The Smithsonian Book of North American Mammals. Edited by D. E. Wilson and S. Ruff. UBC Press, Vancouver, British Columbia. 750 pages.

Cook, J. A., A. M. Runck, and M. J. Conroy. 2004. Historical biogeography at the crossroads of the northern 


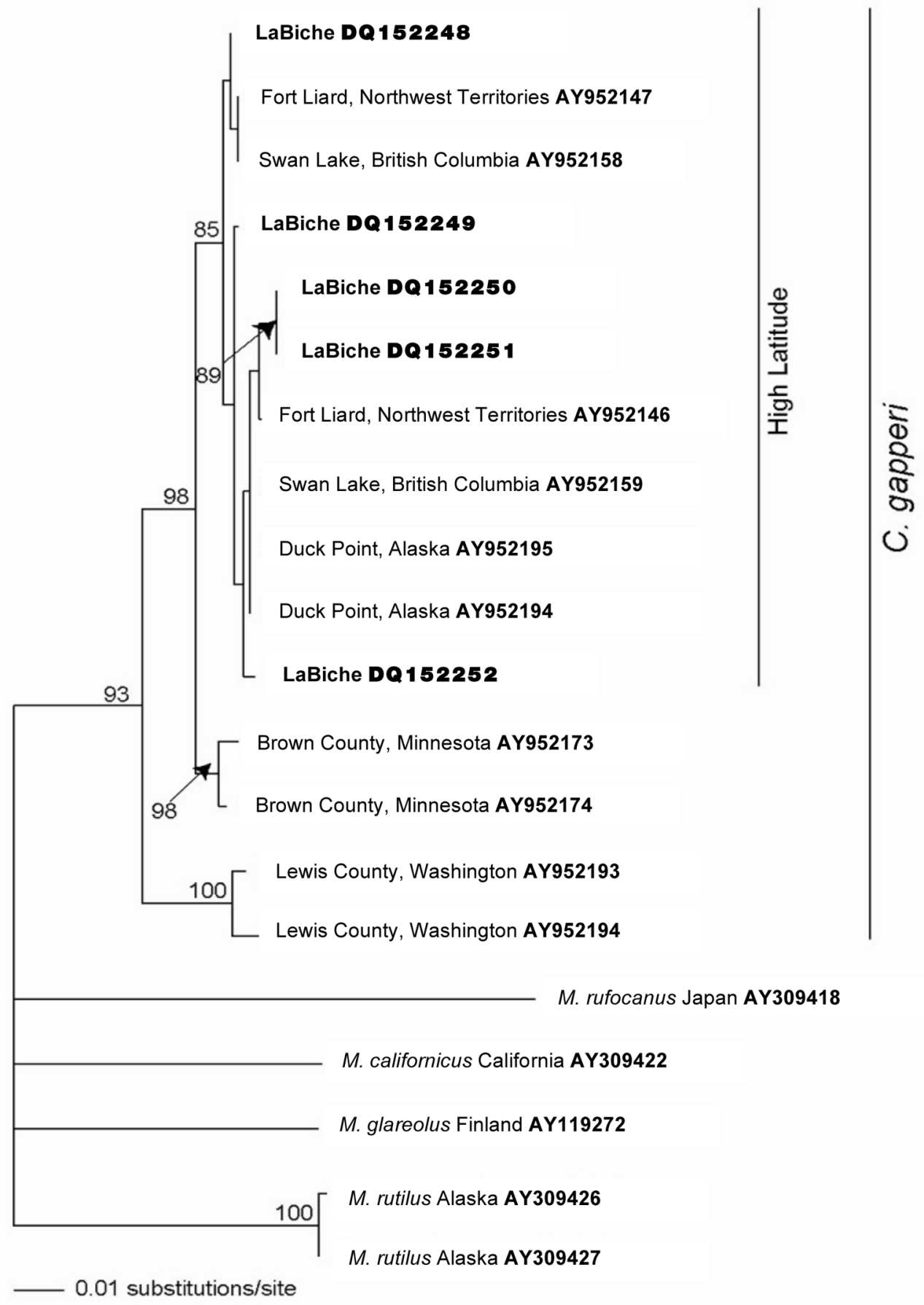

FIGURE 1. Placement of five specimens of Myodes gapperi (LaBiche DQ152248-DQ152252) captured in the LaBiche River Valley, Yukon, based a neighbor-joining analysis of cytochrome $b$ gene sequences $(600 \mathrm{bp})$ of these specimens and compared to sequences of other Myodes. GenBank accession numbers for sequences used are included for each specimen. Numbers above the branches represent bootstrap support values for those nodes. 
continents: molecular phylogenetics of red-backed voles (Rodentia: Arvicolinae). Molecular Phylogenetics and Evolution 30: 767-777.

Eckert, C. D., P. H. Sinclair, and W. A. Nixon. 1997. Breeding bird communities in the forests of the Liard River Valley, Yukon. Technical Report Series Number 297. Canadian Wildlife Service, Delta, British Columbia.

Jung, T. S., B. G. Slough, D. W. Nagorsen, T. A. Dewey, and T. Powell. 2006. First records of the northern longeared bat, Myotis septentrionalis, in the Yukon Territory. Canadian Field-Naturalist 120: 39-42.

McPhee, E. C. 1984. Ethological aspects of mutual exclusion in the parapatric species of Clethrionomys gapperi and C. rutilus. Acta Zoologica Fennica 172: 71-73.

Merritt, J. F. 1981. Clethrionomys gapperi. Mammalian Species 146: 1-9.

Musser, G. G., and M. D. Carleton. 2005. Superfamily Muroidea. In Mammal Species of the world. Edited by D. E. Wilson and D. M. Reeder. John Hopkins University Press, Baltimore, Maryland.

Nagorsen, D. W. 2002. An Identification Manual to the Small Mammals of British Columbia. Ministry of Sustainable Resource Management, Ministry of Water, Land and Air Protection and Royal British Columbia Museum, Victoria, British Columbia. 153 pages.

Nagorsen, D. W. 2005. Rodents and Lagomorphs of British Columbia. Vol. 4: The Mammals of British Columbia.
Royal British Columbia Museum, Victoria, British Columbia. 410 pages.

Posada, D., and K. A. Crandall. 2000. Modeltest: testing the model of DNA substitution. Bioinformatics 14: 817818.

Runck, A. M. 2001. Molecular and morphological perspectives in post-glaciation of Clethrionomys rutilus and Clethrionomys gapperi in southeast Alaska. M.S. thesis, University of Alaska, Fairbanks, Alaska. 89 pages.

Runck, A. M., and J. A. Cook. 2005. Post-glacial colonization of the southern red-backed vole (Clethrionomys gapperi) in North America. Molecular Ecology 14: 1445-1456.

Swofford, D. L. 2002. PAUP*. Phylogenetic analysis using parsimony, Version b10. Sinauer Associates, Sunderland, Massachusetts.

Tamura, K., and M. Nei. 1993. Estimation of the number of nucleotide substitutions in the control region of mitochondrial DNA in humans and chimpanzees. Molecular Biology and Evolution 10: 512-526.

van Zyll de Jong, C. G. 1983. Handbook of Canadian Mammals. 1: Marsupials and Insectivores. National Museums of Canada, Ottawa, Ontario. 210 pages.

Youngman, P. M. 1975. Mammals of the Yukon Territory. National Museums of Canada, Ottawa, Ontario. 192 pages.

Received 12 September 2005

Accepted 4 September 2007 